\title{
指神経内に発生した脂肪線維腫の経験
}

\author{
大分医科大学整形外科教室 \\ 内田和宏・麻生邦一 \\ 内田仁・渡辺寧 \\ 城 日出徳・真 角 昭 吾
}

\section{A Case of Intraneural Lipofibroma of the Digital Nerve}

by

Kazuhiro Uchida, Kuniichi Ahsoh, Hitoshi Uchida, Yasushi Watanabe, Hidenori Jou and Shougo Masumi

Department of Orthopaedic Surgery,

Medical college of Oita, Oita, Japan.

A case of intraneural lipofibroma of the digital nerve is described. The patient was a twentythree-year-old male who had noticed a soft mass in his right palm and middle finger one month ago. The mass increased in size, but he was asymptomatic and there was no loss of function. At surgery, enlarged sausage-shaped, gray-yellow digital nerve was found. Total resection of the mass was impossible because it surrounded the funiculus. Partial resection of the mass was done. Microscopically, the mass consists of fibrofatty tissue that has surrounded and infiltrated nerve trunk and has grown along the epineurium and perineunium.

\section{はじめに}

神経内脂肪線維腫は末梢神経に稀に発生する良性腫 瘍で，末梢神経内に限局して成熟脂肪細胞と線維組織 が增殖したものである. 今回われわれは, 総掌側指神 経より中，環指の固有指神経にまたがって発生した脂 肪線維腫を経験したので報告する.

\section{症例}

症例： 23 才, 男性.

主訴：右手掌および中指の腫瘤。

家族歷，既往歷：特記すべきことなし。

現病歴: 平成元年 9 月右中指掌側の腫瘤に初めて気
づき, 徐々に増大してきたため 10 月当科受診. 血液, 生化学的検查：特記すべきことなし. 初診時所見: 右手掌部より中指にかけ, 弾性軟, 境 界不明瞭な無痛性の腫瘤を触知した。神経症状は認め なかった。

平成元年 11 月手術施行.

手術時所見：総掌側指神経から中, 環指の固有指神経 をとり囲んだ黄色の柔らかい腫瘤を認めた。腫瘤のみ の摘出を試みたが，神経との分離は不可能であったた め, 指神経幹を温存して, 可及的に切除した。切除し た腫瘤は $2 \times 2 \times 7 \mathrm{~cm}$ のソーセージ様で黄白色均一 充実性のものであった。(図 1,2)

病理組織所見：成熟した脂肪細胞の集蔟がみられ， 


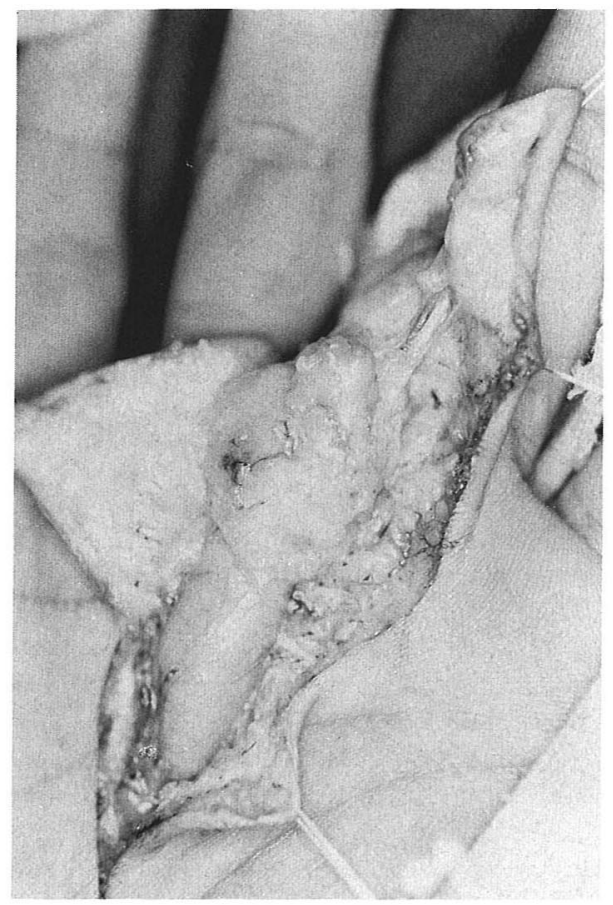

図 1 手術時所見

指神経をとり囲んだ黄色の柔らかい腫溜を認め る.

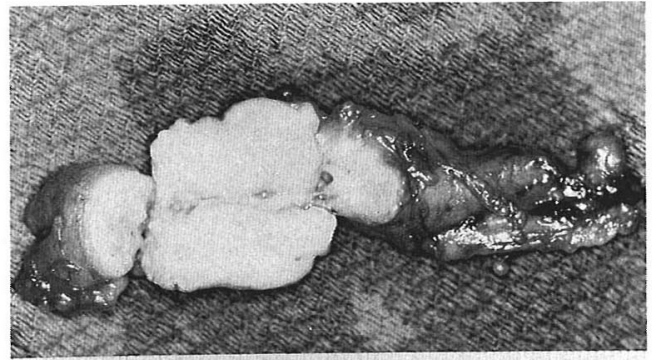

図 2 切除標本

$2 \times 2 \times 7 \mathrm{~cm}$, ソーセージ様, 黄白色均一, 充 実性の腫瘤である。

神経線維と平行に走る線維組織よりなっていた。神経 線維は神経周膜の線維性增生を認め，神経内脂肪線維 腫と診断した。(図 3 )

術後は中，環指に軽度の知覚鈍麻を認めたが，経過 とともに回復してきている。

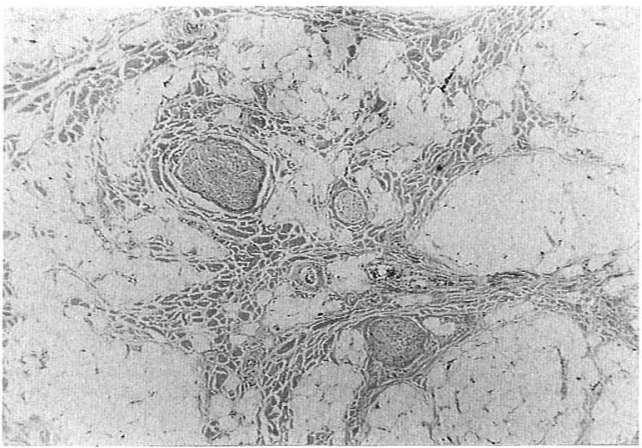

図 3 A 病理組織所見

神経束をとり囲んで成熟脂肪細胞と線維組織 が増殖している.

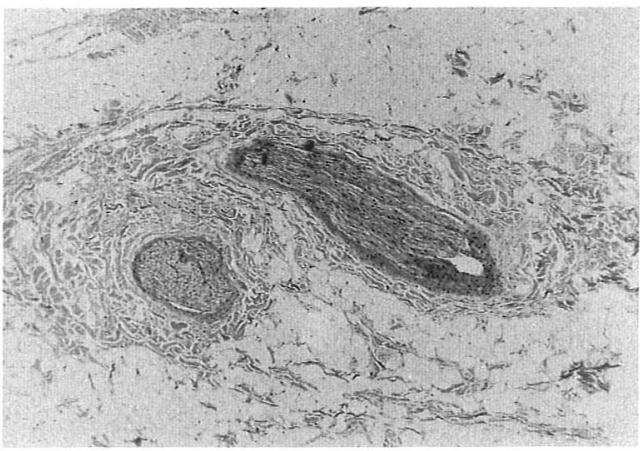

図 3 B 神経束周囲の線維性増殖をみとめる。

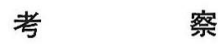

1952 年 Mason ${ }^{9)}$ が末梢神経内に成熟した脂肪細胞 及び線維組織の増殖を初めて報告しているが, その後 intraneural fibrolipoma, lipofibroma ${ }^{5) 12)}$, fibrofatty proliferation $^{2)}$, lipomatous hamartoma ${ }^{3)}$ などさまざ まな名称での報告がある。病因は腫瘍説，過誤腫説も しくは単に脂肪組織の増殖とする説 ${ }^{2)}$ に大別される が, 末だ結論は得られていない.また macrodactylyに 伴った例もみられ, Silverman ら ${ }^{14)}$ は 26 例中 7 例に, Amadio $ら^{1)} 18$ 例中 12 例に macrodactyly の合併 を報告している。

われわれがこれまでに渉猟し得た症例は 78 例であ り，自験例を含め検討すると，発症年令は若年者が多 く,生下時に認められることもある.Silverman ${ }^{14)}$ は 26 例中 10 例は生下時もしくは 2 才前に大きくなったも のであると報告している。発生部位の大半は上肢であ 
り, 手関節付近より末梢の正中神経に多い. 臨床症状 及び所見としては，徐々に増大する柔らかい腫瘤を触 知し, 病状が進行すれば, 知覚障害, 運動障害を起こ すことがある。鑑別疾患は, intraneural lipoma, neurofibromatosis, Dejerine-Sottas 病などがあげられる が, 確定診断には生検が必要である. 病理組織所見と して, 神経内に線維脂肪組織が浸潤し, 神経外膜, 神 経周膜の線維性増殖がみられることが特徵的である. 神経内に浸潤しているため神経を温存して腫瘍の全摘 出は不可能であり, 治療法は神経の除圧のみにとどめ る方法 ${ }^{4) 715)}$ と切除もしくは切除後神経移植を行う方 法11)があるが，未だ確立されていない.

Louis $ら^{8)}$ は腫場切除後, 平均 11 年の長期経過観察 の 4 例において神経症状の悪化を認め, この疾患に対 する治療の難しさを述べている. 本症は, 術前神経症 状がみとめられなかったため, 神経幹の温存を重視し, 可及的な切除にとどめた. 術後 1 年では経過は良好で あるが今後長期間の観察が必要である.

\section{ま と め}

1）指神経内に発生した脂肪線維腫の一例を経験し た.

2）治療は指神経幹を残して可及的に腫瘍を切除し た.

3）病名および治療法につき考察した.

\section{参 考 文 献}

1) Amadio, P.C. et al.: Lipofibromatous hamartoma of nerve. J. Hand Surg., 13-A : 67-75, 1988.

2) Callison, J.R. et al. : Fibrofatty proliferation of the median nerve. Plast. Reconst.Surg,42 : 403-413,
1968.

3) Emmett, A. J. : Lipomatous hamartoma of the median nerve in the palm. Br. J. Plast. Surg., 18: 208213.

4) Houpt, P. et al. : Intraneural lipofibroma of the median nerve. J. Hand Surg., 14 A : 706-709, 1989.

5) Jacob, R. A. et al. : Lipofibroma of superficial branch of fhe radial nerve. J. Hand Surg., 14-A : 704706, 1989.

6）加藤貞文・他：左肘関節部の正中神経内に発生した緎 維脂肪腫の一例. 東北整災紀要, $32: 161-163,1988$.

7) Langa, V.et al.: Lipofibroma of the median nerve: A report of two cases. J.Hand Surg., 12-B : 221-223, 1987.

8) Louis, D. S. et al.: Lipofibromas of the median nerve: Longterm follow-up of four cases., J. Hand Surg., 10-A : 403-408, 1985.

9) Mason, M.L. : Presentation of cases. In proceeding of American society surgery of the hand. J. Bone Joint Surg., 35-A : 273-274, 1953.

10）大越康充・他：Guyon 管症候群を呈した intraneural lipofibroma の一例. 日形会誌, $6: 179-184,1986$.

11) Paletta, F. X. and Senay. L. C. : Lipofibromatous hamartoma of median nerve and ulner nerve : Surgical treatment. Plast. Reconstr. Surg., 68: 915-921, 1981.

12) Rowland, S. A.: Case report: Ten year follow-up of lipofibroma of the median nerve in the plam. J. Hand Surg., 2 : 316-317, 1977.

13）佐久間克彦·他：正中神経内脂肪腫の一症例. 整形外 科と災害外科 $37: 841-844,1988$.

14) Silverman, T.A. and Enzinger, F. M.: Fibrolipomatous hamartoma of nerve. Am. J. Surg. Pathol., 9 : 7-14, 1985.

15) Sondergaard, G. and Mikkelsen, S. : Fibrolipomatous hamartoma of the median nerve. J. Hand Surg., 12-B : 224-226, 1987. 